\title{
Assessment of pollution in water quality of oil and grease for Tigris River-Iraq by GIS mapping (2010-2016)
}

\author{
Ibtihal Mawlood ${ }^{1}$, Abdul-Razzak Ziboon ${ }^{1}$ and Abdul-Hammed Al-Obaidy ${ }^{2}$ \\ ${ }^{1}$ Building and Construction Engineering Department, University of Technology, Baghdad, Iraq \\ ${ }^{2}$ Environmental Research Center, University of Technology, Baghdad, Iraq
}

\begin{abstract}
In this study have followed the oils and grease in Tigris River within Baghdad city during the period 2010-2015 by using ArcGIS 10.2 program. Two satellite image of each year were used which were taken in as same time as collected samples and painted the mapping which show the locations of pollution the river by oil and grease. This study showed the Tigris river is pollution by the oil and grease, and the values were up limit allowable depend on the world health organization (who) and Iraqi criteria.
\end{abstract}

\section{Introduction}

Remote sensing techniques play increasingly important role over recent decades in both problems of global climate change and frequent deterioration of the status of aquatic ecology, driven by the ever-increasing needs of growing populations for drinking water, polluted by overland runoff from point and non-point sources, as well as fish and other seafood [1]. With the advent of new sensor technologies, it is possible to monitor land cover / land change in large area simultaneously and quickly $[2,3]$. Remote sensing techniques have been widely used in water quality assessment $[4,5$ and 6$]$.

Many documents describe water quality monitoring using different satellite sensor [4, 7]. The spectrum characteristics of water and pollutants are essential to water quality monitoring and assessment. The spectral characteristics of the signal received from water are a function of hydrological, biological and chemical characteristics of water, and other interference factor [8]. Suspended sediments increase the radiance emergent from surface waters in the visible and near infrared proportion of the electromagnetic spectrum [9] so it is promising and feasible to detect water

Pollutants using spectral signatures in the visible and near infrared band. Tigris River is course water alone in Bagdad city in addition The Tigris has long been an important transport route in a largely desert country. Shallow-draft vessels can go as far as Baghdad.

The Tigris is heavily dammed in Iraq and Turkey to provide water for irrigating the arid and semi-desert regions bordering the river valley. Damming has also been important for averting floods in Iraq, to which the Tigris has historically been notoriously prone following April melting of snow in the Turkish mountains.

Recent Turkish damming of the river has been the subject of some controversy, for both its environmental effects within Turkey and its potential to reduce the flow of water downstream.

Water from both countries is used as a means of pressure during conflicts. [10]

In 2014 a major breakthrough in developing consensus between multiple stakeholder representatives of Iraq and Turkey on a Plan of Action for promoting exchange and calibration of data and standards pertaining to Tigris river flows was achieved. The consensus which is referred to as the "Geneva Consensus on Tigris River" was reached at a meeting organized in Geneva by the think tank Strategic Foresight Group. [11]

All that, Lead to save the river from any problem expose on it, and monitor the river periodically.

\section{Study Area}

The Tigris River is one of the largest rivers in Iraq, and is considered the main source of drinking water for Baghdad, which is the largest city in the country and the second largest city in the Arab world with a population estimated by 7.5 million $[4,11]$. 
The River enters Baghdad city at coordinates $44^{\circ} 24^{\prime} \mathrm{E}, 33^{\circ} 36^{\prime} \mathrm{N}$ and divides the city into two parts (Karkh \& Risafa). The length of the river along Baghdad city is about $110 \mathrm{~km}$. The samples collected from seven sites in the river as the show in table (1) and the figure (1) in the same time took the satellite image.

Table 1. Location of samples in study area

\begin{tabular}{|c|c|c|c|}
\hline site & Location & \multicolumn{2}{|c|}{ Coordinate } \\
\hline Site 1 & $\begin{array}{l}\text { Al-Muthanna } \\
\text { Bridge }\end{array}$ & Lon: $44^{0} 20^{\prime} 46^{\prime \prime}$ & $\begin{array}{l}\text { Lat: } \\
33^{0} 25^{\prime} 32^{\prime \prime}\end{array}$ \\
\hline Site2 & Al-A'imma bridge & Lon: $44^{0} 211^{\prime \prime} 19^{\prime \prime}$ & Lat: $33^{0} 2228$ \\
\hline Site 3 & Al-Shuhada Bridge & Lon: $44^{0} 23^{\prime} 16^{\prime \prime}$ & Lat: $33^{0} 20^{\prime} 17$ \\
\hline Site 4 & $\begin{array}{l}\text { Al- Jumhuiya } \\
\text { Bridge }\end{array}$ & Lon: $44^{0} 26^{\prime} 31^{\prime \prime}$ & Lat: $33^{0} 19^{\prime} 28$ \\
\hline Site 5 & Al- Jadriah Bridge & Lon: $44^{0} 2^{3^{\prime}} 09^{\prime \prime}$ & Lat: $33^{0} 17^{\prime} 26$ \\
\hline Site 6 & Al- Rasheed w.w & Lon: $44^{0} 22^{\prime} 55^{\prime \prime}$ & Lat: $33^{0} 15^{\prime} 43$ \\
\hline Site 7 & Al- Doura w.w & Lon: $44^{0} 27^{\prime} 15^{\prime \prime}$ & Lat: $33^{0} 16^{\prime} 17$ \\
\hline
\end{tabular}

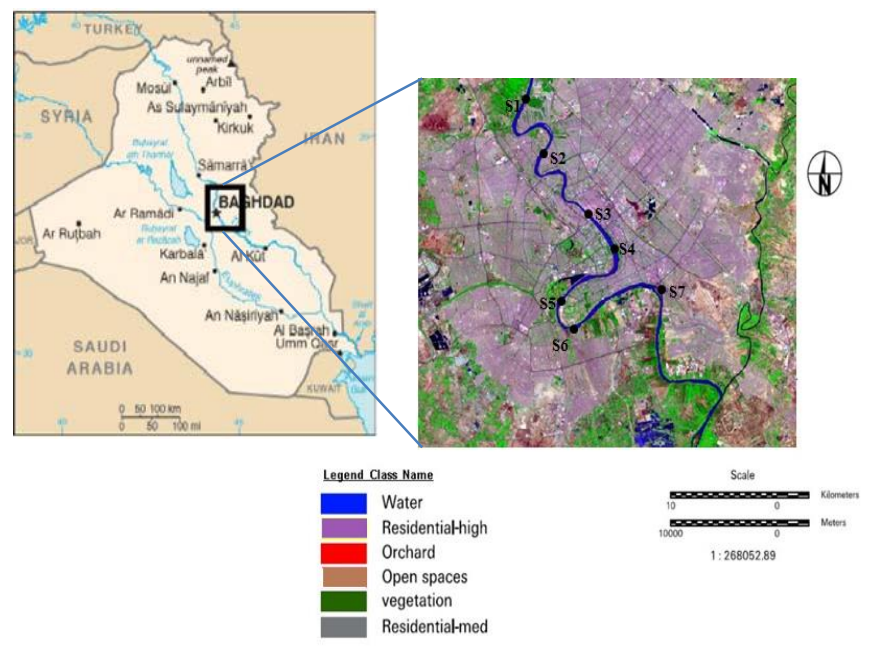

Fig 1: shows the site of sample in Tigris River

\section{Materials and methods}

The satellite images from the Landsat archived on United States Geological Survey (USGS) server (http://earthexplorer.usgs.gov/) were used in this study. The Landsat Enhanced Thematic Mapper plus (ETM+) image was acquired in (2010-2016).All images employed in this study are level-1 products of the USGS. They are referenced in the World Geodetic System (WGS84) datum, in GeoTiff format, and are projected using the Universal Transverse Mercator system (zone UTM 38 North).

Geographical Information system (GIS) is a computerbased technology for handling geographical data in digital form. It is designed to capture, store, manipulate, analyze, and display diverse sets of spatial or geo-referenced data $[12,13]$. Coordinates of sampling points were recorded by mobile GPS (Etrax). The results of the chemicals analysis (mean value per sampling point) were then used as input data in ArcGIS 10.2. The sampling locations were integrated with the water data for the generation of spatial distribution maps. The present study used the Inverse Distance Weighted (IDW) method for spatial interpolation of water parameters. IDW determines cell values using a liner-weighted combination set of sample points. The weight assigned is a function of the distance of an input point from the output cell location. The greater the distance, the less influence the cell has on the output value [14]

The Analyzing based on contaminant concentration change in the river from the low concentration to high concentration, where this indicates that the presence of contamination points in that region and Search for these points sources of pollution of the river.

\subsection{Oils and grease (O\&G)}

The concentration of single oils and grease (OG) is an important limitation for water quality and safety. $O G$ in water can reason surface films and shoreline deposits leading to environmental degradation, and can induce human health risks when discharged in surface or ground waters. Also, OG might interfere with aerobic and anaerobic biological processes and lead to declined wastewater treatment efficiency. Regulatory bodies worldwide set limits in order to control the amount of OG incoming natural bodies of water or reservoirs through industrial discharges, and to boundary the amount present in drinking water.

OG in water is normally determined by extraction into a non-polar, hydrocarbon free solvent followed by quantity of the infrared absorption spectrum of the extract. The absorption between 3000 and $2900 \mathrm{~cm}-1$ by C-H sets in the $\mathrm{OG}$ is connected to the concentration of OG. There are several standard check protocols based around this methodology, 1-4 most usually using 1, 1, 2-trichloro-1, 2, 2-trifluoroethane (CFC-113) or tetra-chloromethane.

Though, these solvents are identified ozone-depleting compounds, and under the Montreal Protocol, the use of CFC-113 WAS PHASED OUT BY 1996 AND THE USE OF TETRA-chloromethane will develop illegal in 2010[15].

\section{Results and Discussion}

Figures from (2) to (9) have shown the classification of Tigris river according to O\&G during the period 20102016.The Iraqi Ministry of health Stipulated on maximum concentration of $O \& G$ is up stream of $(0.1 \mathrm{mg} / \mathrm{l})$.all maps show increased about concentration up of the limit in all 
sites, as seen in figure (11)

Source of pollution in Tigris River: in through compare between the satellite images and determined the change in points from low concentration to high concentration, it can be determined the most important of source pollution in Tigris River depend on the drawing maps in this study and information from Field survey of the study area and the Department of Environment Baghdad and the Iraqi Ministry of Water Resources. As seen in Figure (10) and table (2)

\begin{tabular}{|c|c|c|c|}
\hline STATION & COORDINATES & $\begin{array}{l}\text { RESPONSIB } \\
\text { LE }\end{array}$ & $\begin{array}{l}\text { DISCHA } \\
\text { RGE } \\
\text { L/SEC }\end{array}$ \\
\hline $\begin{array}{l}\text { RAINS STATION AL- } \\
\text { MASBAH }\end{array}$ & $\begin{array}{l}\text { N } 33017^{\prime} 54.6^{\prime \prime} \\
\text { E } 044025^{\prime} 55.1\end{array}$ & $\begin{array}{l}\text { Al-karrada } \\
\text { municipality }\end{array}$ & 360 \\
\hline $\begin{array}{l}\text { RAINS STATION AL- } \\
\text { JADRIAH }\end{array}$ & $\begin{array}{l}\text { N } 33017^{\prime} 32.5^{\prime \prime} \\
\text { E } 044023^{\prime} 28.2^{\prime \prime}\end{array}$ & $\begin{array}{l}\text { Al-karrada } \\
\text { municipality }\end{array}$ & 1500 \\
\hline $\begin{array}{l}\text { RAINS STATION AL- } \\
\text { HURIYA }\end{array}$ & $\begin{array}{l}\text { N } 33024^{\prime} 37.2^{\prime \prime} \\
\text { E } 044026^{\prime} 48.4^{\prime \prime}\end{array}$ & $\begin{array}{l}\text { Al-karrada } \\
\text { municipality }\end{array}$ & 420 \\
\hline $\begin{array}{l}\text { RAINS STATION AL- } \\
\text { RASHEED }\end{array}$ & $\begin{array}{l}\text { N } 33017^{\prime} 41.4^{\prime \prime} \\
\text { E } 044027^{\prime} 11.6^{\prime \prime}\end{array}$ & $\begin{array}{l}\text { Al-karrada } \\
\text { municipality }\end{array}$ & 4500 \\
\hline RAINS STATION SHIP & $\begin{array}{l}\text { N } 33022^{\prime} 02.2^{\prime \prime} \\
\text { E } 044021^{\prime} 20.6^{\prime \prime}\end{array}$ & $\begin{array}{l}\text { Al-adhamiya } \\
\text { municipality }\end{array}$ & 285 \\
\hline RAINS STATION A1 & $\begin{array}{l}\text { N } 33023^{\prime} 28.2^{\prime \prime} \\
\text { E } 044021^{\prime} 35.7^{\prime \prime}\end{array}$ & $\begin{array}{l}\text { Al-adhamiya } \\
\text { municipality }\end{array}$ & 3200 \\
\hline $\begin{array}{l}\text { RAINS STATION AL- } \\
\text { KUWAITY }\end{array}$ & $\begin{array}{l}\text { N } 33024^{\prime} 10.5^{\prime \prime} \\
\text { E } 044020^{\prime} 24.2^{\prime \prime}\end{array}$ & $\begin{array}{l}\text { Al-adhamiya } \\
\text { municipality }\end{array}$ & 390 \\
\hline RAIN STATION T1 & $\begin{array}{l}\text { N } 33021^{\prime} 05.7^{\prime \prime} \\
\text { E } 044022^{\prime} 29.0^{\prime \prime}\end{array}$ & $\begin{array}{l}\text { Municipality } \\
\text { rusafa center }\end{array}$ & 15000 \\
\hline $\begin{array}{l}\text { RAIN STATION PN- } \\
\text { AL-SAIDIYA }\end{array}$ & $\begin{array}{l}\text { N } 33016^{\prime} 05.5^{\prime \prime} \\
\text { E } 044022^{\prime 2} 20.5^{\prime \prime}\end{array}$ & $\begin{array}{l}\text { Rasheed } \\
\text { municipality }\end{array}$ & 18000 \\
\hline $\begin{array}{lr}\text { RAIN } & \text { STATION } \\
\text { ABDUL MOHSEN AL- } \\
\text { KAZEMI PUMPING }\end{array}$ & $\begin{array}{l}\text { N } 33021^{\prime} 59.2^{\prime \prime} \\
\text { E } 044020^{\prime} 43.8^{\prime \prime}\end{array}$ & $\begin{array}{l}\text { Kadhimiya } \\
\text { municipality }\end{array}$ & 9000 \\
\hline
\end{tabular}

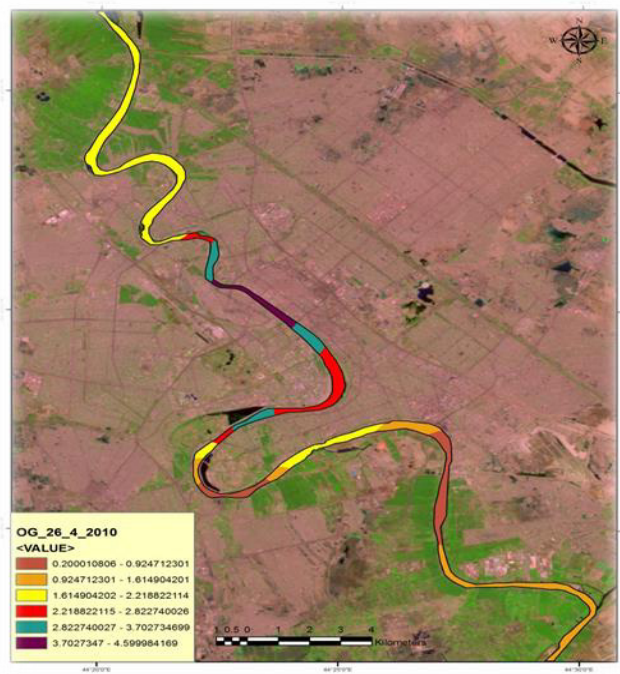

Fig 2: shows the classification of Tigris River by oils and grease in April 2010

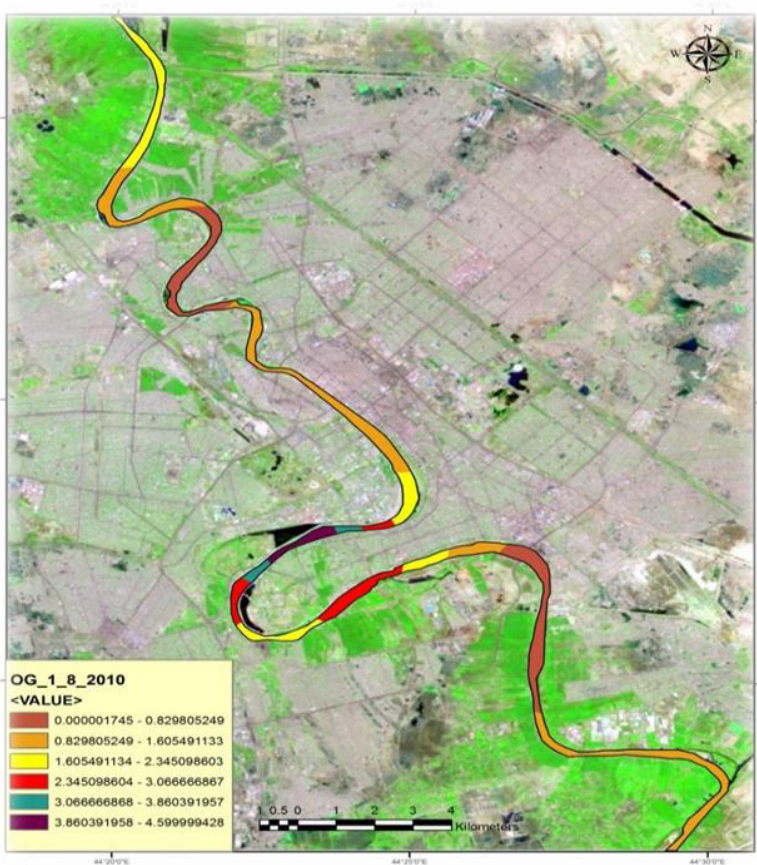

Fig 3: shows the classification of Tigris River by oils and grease in Aug. 2010

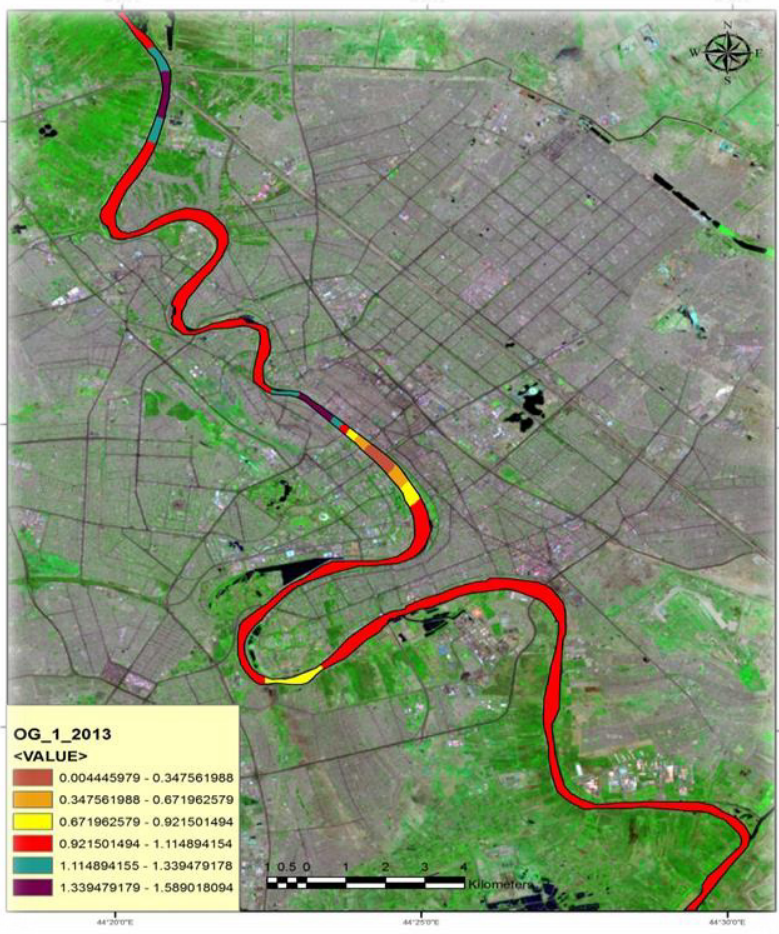

Fig 4: shows the classification of Tigris River by oils and grease in Janu 2013 


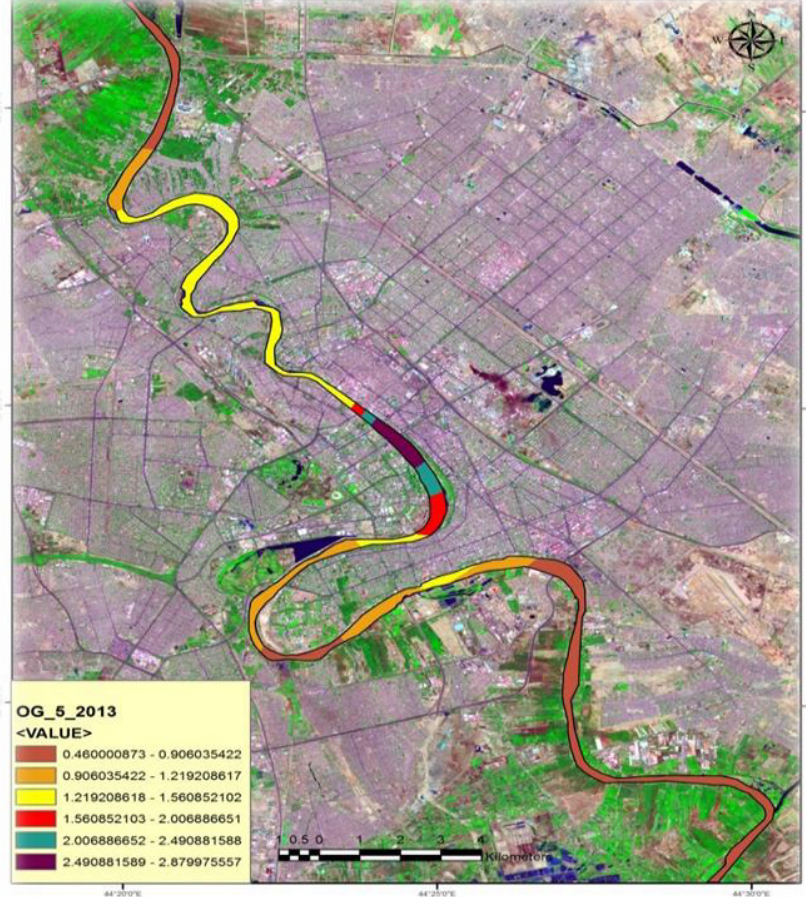

Fig 5: shows the classification of Tigris River by oils and grease in May 2013

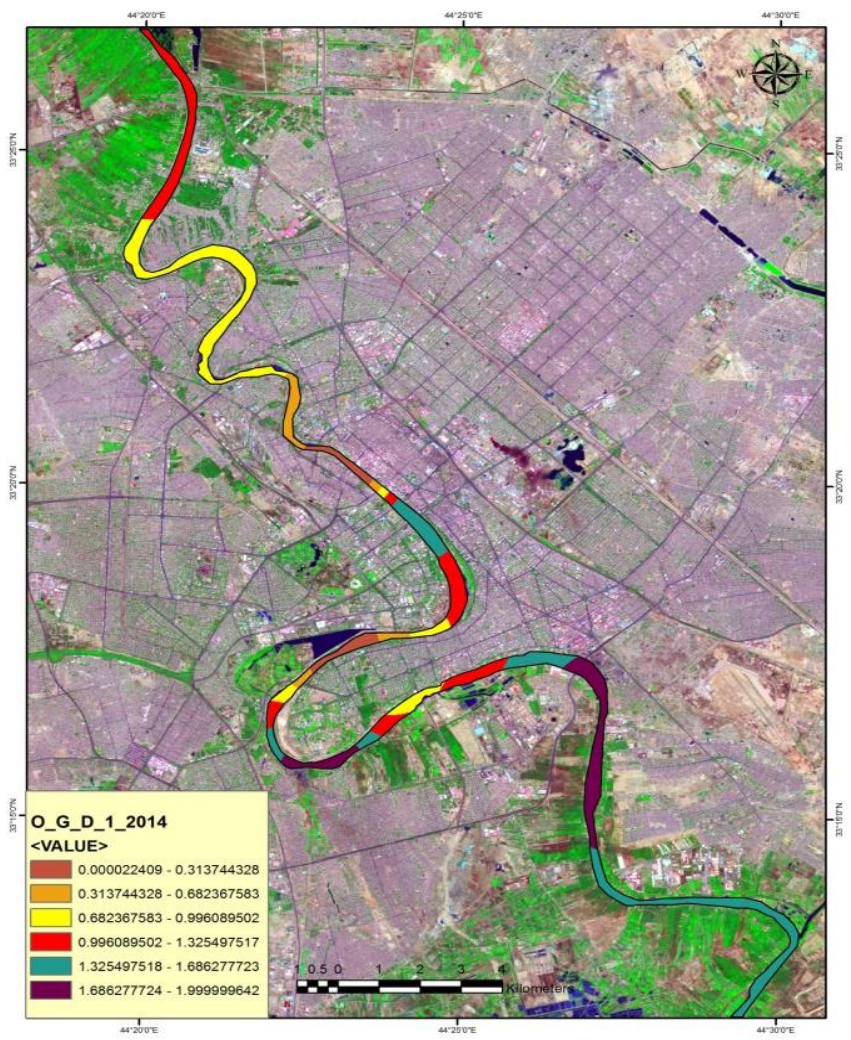

Fig 6: shows the classification of Tigris River by oils and grease in Janu 2013

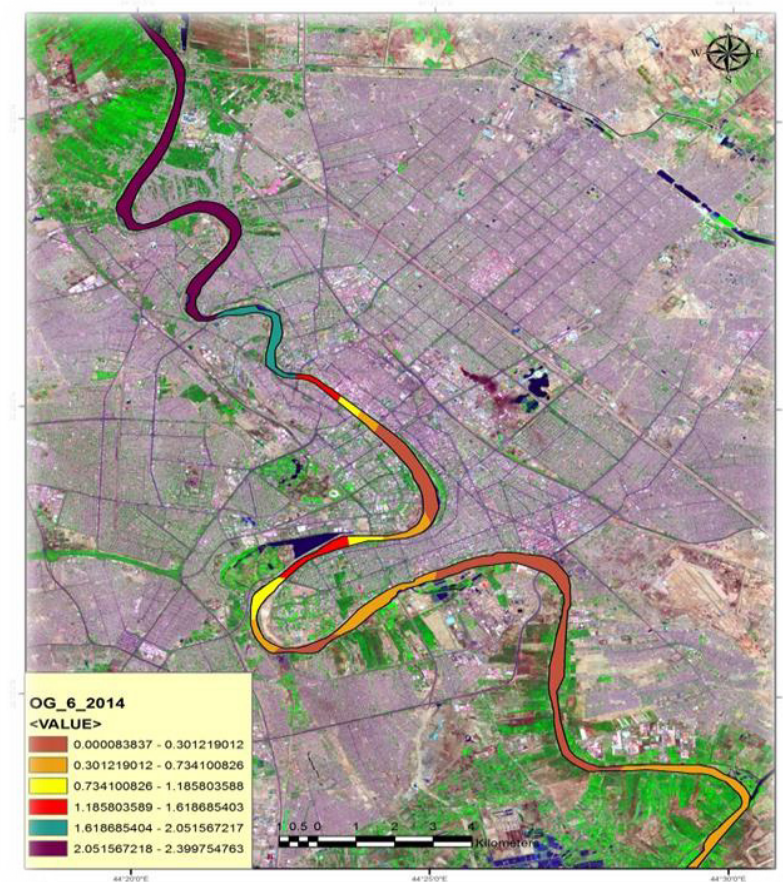

Fig 7: shows the classification of Tigris River by oils and grease in Jun 2014

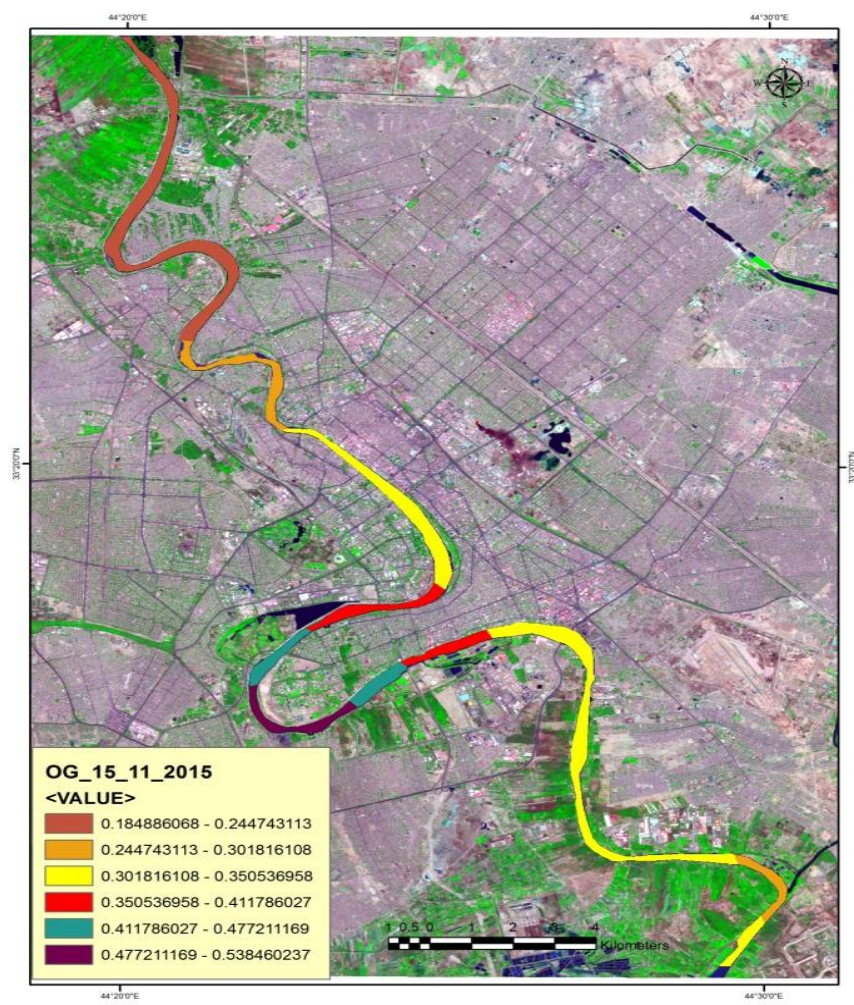

Fig 8: shows the classification of Tigris River by oils and grease in Nov. 2015 


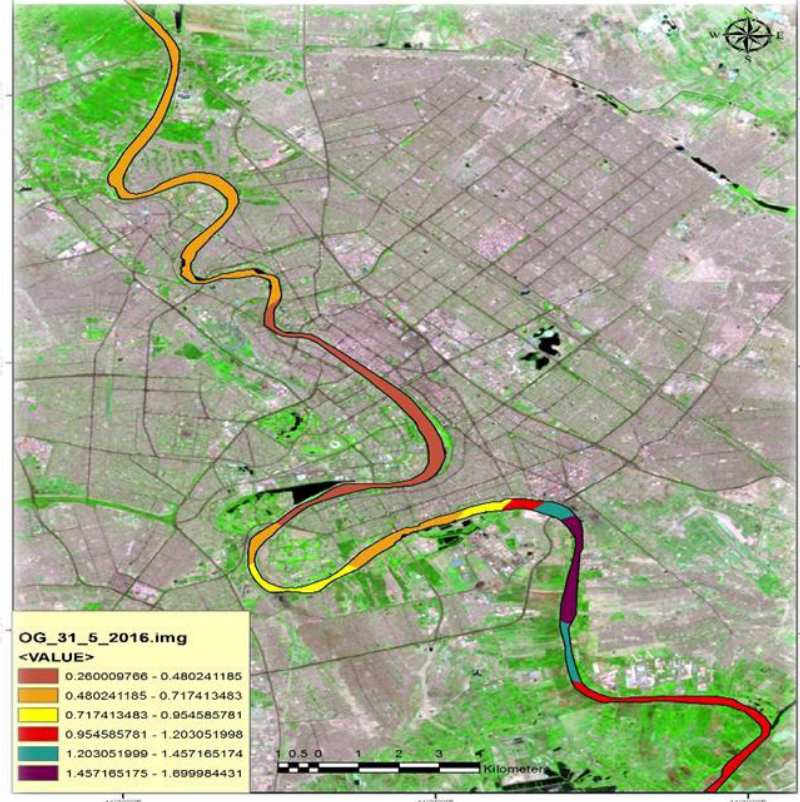

Fig 9: shows the classification of Tigris River by oils and grease in May 2016

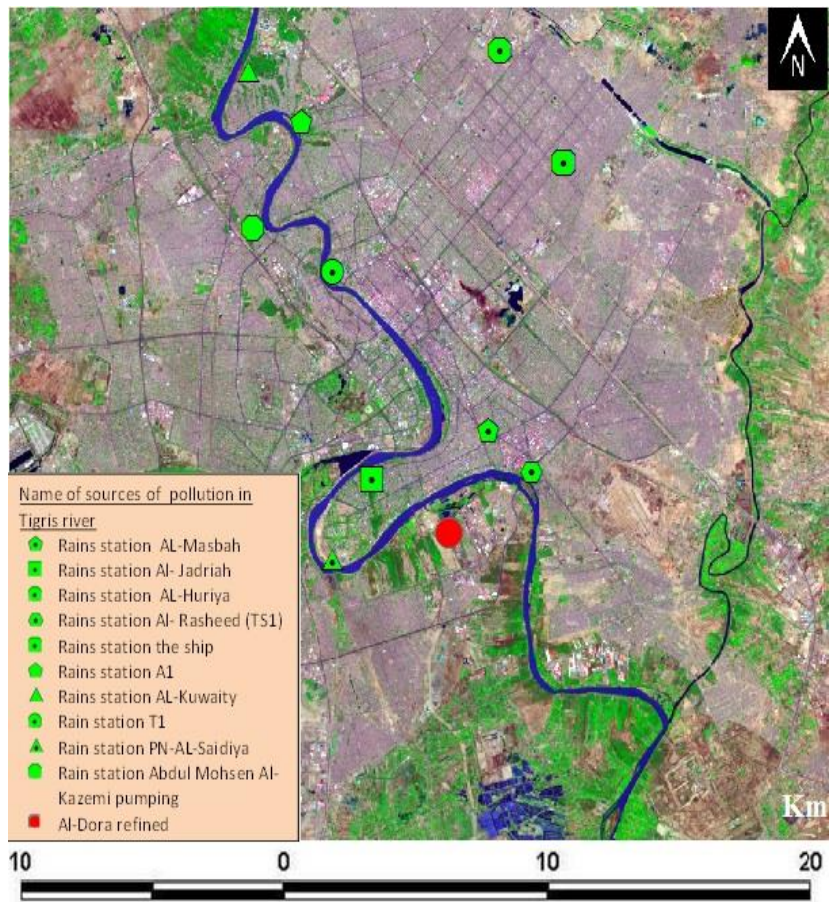

Fig 10: shows the Source of pollution by oils and grease in Tigris River

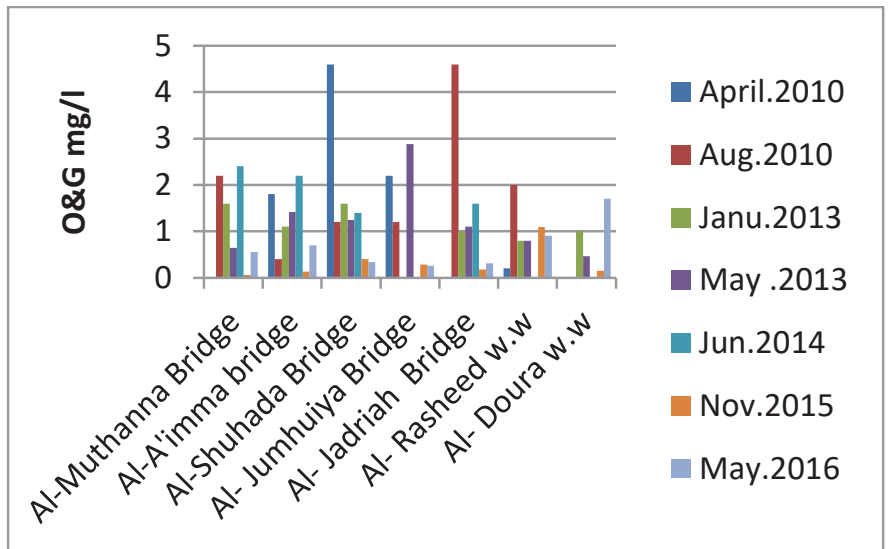

Fig 11: shows Historical changes in the tested water quality (Oils and Grease) in Tigris River

\section{References}

[1]Pozdnyakov, D., Shuchman, R., Korosov, A. \& Hatt, C. (2005). Operational algorithm for the retrieval of water quality in the Great Lakes. Remote Sensing of Environment, Vol. 97, No. 3, 352-370.

[2] Wen, X. \& Yang, X. (2009a). Change detection from remote sensing imageries using spectral change vector analysis. Asia-Pacific Conference on Information Processing (APCIP2009), 189-192, IEEE Computer Society, Shenzhen, China

[3] Wen, X. \& Yang, X. (2009b). A new change detection method for two remote sensing images based on spectral matching. International Conference on Industrial Mechatronics and Automation (ICIMA 2009), 89-92, IEEE Computer Society, Chengdu, China

[4]Alparslan, E., Aydener, C., Tufekci, V. \& Tüfekci, H. (2007). Water quality assessment at Omerli Dam using remote sensing techniques. Environmental Monitoring and Assessment, Vol. 135, No. 1, 391-398

[5]Brando, V. E. \& Dekker, A. G. (2003). Satellite hyperspectral remote sensing for estimating estuarine and coastal water quality. Geoscience and Remote Sensing, IEEE Transactions on, Vol. 41, No. 6, 1378-1387.

[6]Chen, Q.; Zhang, Y. \& Hallikainen, M. (2007). Water quality monitoring using remote sensing in support of the EU water framework directive (WFD): A case study in the Gulf of Finland. Environmental Monitoring and Assessment, Vol. 124, No. 1, 157-166.

[7]Boken, V. K. (2007). Linking landuse and groundwater quality in the Mississippi delta Using MODIS satellite data. IEEE International Geoscience and Remote Sensing Symposium, 5025-5027,

[8]Seyhan, E. \& Dekker, A. (1986). Application of remote sensing techniques for water quality monitoring. Aquatic Ecology, Vol. 20, No. 1, 41-50.

[9]Ritchie, J.; Zimba, P. \& Everitt, J. (2003). Remote sensing techniques to assess water quality. Photogrammetric Engineering and Remote Sensing, Vol. 69, No. 6, 695-704. 
[10]Vidal, John. "Water supply key to outcome of conflicts in Iraq and Syria, experts warn" The Guardian, 2 July 2014.

[11]"Analysis \& Water Agenda". ORSAM. Retrieved 2015-11-28

[12]V. P. Singh and M. Fiorentino, "Geographic Information System in Hydrology," Kluwer Academic Publishers, Dordrecht, 1996.

[13]Y. Saeedrashed and A. Guven, "Estimation of Geomor- phological Parameters of Lower Zab River-Basin by Us-ing GIS-Based Remotely Sensed Image," Water Resour- ces Management, Vol. 27, No. 1, 2013, pp. 209219. http://dx.doi.org/10.1007/s11269-012-0179-x

[14]C. Childs, "Interpolation Surfaces in ArcGIS Spatial Analyst," ESRI Education Services, 2004. www.seri.com [15] Chapman. D., 1996. Water Quality Assessments - A Guide to Use of Biota, Sediments and water in Environmental Monitoring. Second ed. Great Britain at the University Press, Cambridge: UNESCO/WHO/UNEP. 